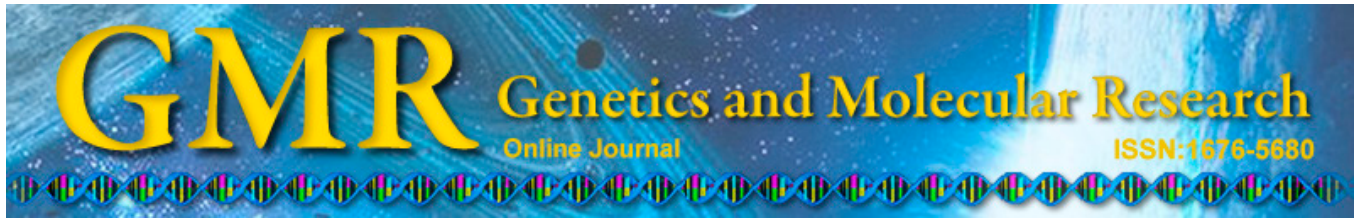

\title{
Evaluation of microsatellite loci from libraries derived from the wild diploid 'Calcutta 4' and 'Ouro' banana cultivars
}

\author{
P.R.O. Silva ${ }^{1}$, O.N.J. Jesus ${ }^{2}$, S. Creste ${ }^{3}$, A. Figueira ${ }^{4}$, E.P. Amorim ${ }^{2}$ and \\ C.F. Ferreira ${ }^{2}$ \\ ${ }^{1}$ Núcleo de Biotecnologia, Universidade Federal do Recôncavo da Bahia, \\ Cruz das Almas, BA, Brasil \\ ${ }^{2}$ Núcleo de Biologia Avançada, Embrapa Mandioca e Fruticultura, \\ Cruz das Almas, BA, Brasil \\ ${ }^{3}$ Instituto Agrômico de Campinas, Campinas, SP, Brasil \\ ${ }^{4}$ Centro de Energia Nuclear na Agricultura, Universidade de São Paulo, \\ Piracicaba, SP, Brasil \\ Corresponding author: C.F. Ferreira \\ E-mail: claudia.ferreira@embrapa.br
}

Genet. Mol. Res. 14 (3): 11410-11428 (2015)

Received January 14, 2015

Accepted May 15, 2015

Published September 25, 2015

DOI http://dx.doi.org/10.4238/2015.September.25.9

\begin{abstract}
Microsatellite markers have been widely used in the quantification of genetic variability and for genetic breeding in Musa spp. The objective of the present study was to evaluate the discriminatory power of microsatellite markers derived from 'Calcutta 4' and 'Ouro' genomic libraries, and to analyze the genetic variability among 30 banana accessions. Thirty-eight markers were used: 15 from the 'Ouro' library and 23 from the 'Calcutta 4' library. Genetic diversity was evaluated by considering SSR markers as both dominant markers because of the presence of triploid accessions, and co-dominant markers. For the dominant analysis, polymorphism information content (PIC) values for 44 polymorphic markers ranged from 0.063 to 0.533 , with a mean value of 0.24 . A dendrogram analysis separated the BGB-Banana accessions into 4 groups: the 'Ouro'
\end{abstract}


and 'Muísa Tia' accessions were the most dissimilar (93\% dissimilarity), while the most similar accessions were 'Pacovan' and 'Walha'. The mean genetic distance between samples was 0.74 . For the analysis considering SSR markers as co-dominants, using only diploid accessions, two groups were separated based on their genome contents (A and B). The PIC values for the markers from the 'Calcutta 4 ' library varied from 0.4836 to 0.7886 , whereas those from the 'Ouro' library ranged from 0.3800 to 0.7521 . Given the high PIC values, the markers from both the libraries showed high discriminatory power, and can therefore be widely applied for analysis of genetic diversity, population structures, and linkage mapping in Musa spp.

Key words: Genetic variability; Molecular characterization; Musa spp; Microsatellites

\section{INTRODUCTION}

Bananas have considerable economic and social importance worldwide, and they are cultivated by small, medium, and large producers across tropical and subtropical regions. In 2013, Brazil was ranked fifth among banana producing countries, with 503,354 hectares of cultivated area and production of 7.3 million tons of bananas (FAO, 2014). Bananas are the fourth most consumed food worldwide, and the most consumed fruit in Brazil (Anuário Brasileiro da Fruticultura, 2014).

Although a large number of cultivars are found in Brazil, only a small proportion has agronomic potential for commercial production because of market demands with respect to plant height, yield, and the size and quality of fruits. One solution to the problem of a limited number of commercial cultivars is the selection of new genotypes with superior characteristics (Silva et al., 2013), a selection process that is benefited by the use of molecular markers. Banana breeding at Embrapa Cassava and Fruits has generated promising triploid and tetraploid hybrids via crosses between genetically improved triploid and diploid cultivars. These hybrids show interesting agronomic traits, such as resistance to common pests, improved physical and chemical fruit quality, and relatively small plants (Amorim et al., 2013). Banana production is usually based on triploid cultivars; however, diploids are of great importance because they are the source of many alleles that confer resistance and tolerance to biological and abiotic factors. Thus, the evaluation of these diploid accessions provides crucial information for breeding programs.

Molecular markers are valuable tools for breeders, especially for the selection of parental genotypes and for the evaluation of genetic diversity among accessions in germplasm collections. Furthermore, molecular markers have contributed to basic crop genetics and understanding of plant characteristics, and to the development of genetically improved organisms (Ferreira and Grattapaglia, 1998). Molecular markers are also useful for studies of many aspects of the biology of banana plants, such as taxonomy, genotyping, and evolution (Amorim et al., 2008; D'Hont et al., 2012; Jesus et al., 2013) and for linkage map saturation (Fauré et al., 1993; Mbanjo et al., 2009; Hippolyte et al., 2010).

Various types of molecular markers have been developed; among the most widely used are microsatellites, also called simple sequence repeats (SSRs). Studies have been performed in blueberries (Silva et al., 2008), Barbados cherries (Salla et al., 2002), avocados (Sharon et al., 1997; Borrone et al., 2009), and bananas (Jesus et al., 2006, 2009; Amorim et al., 2009) with molecular markers. The use of these markers requires only small amounts of plant DNA, 
and they are easily detected by PCR while having wide genomic coverage (Buso et al., 2003). One of the greatest advantages of microsatellite markers over other PCR-based methods is their co-dominant nature, which allows the estimation of allelic relationships between individuals (Crouch et al., 1998).

The development and validation of new microsatellites from Musa spp cultivars will undoubtedly provide robust information that will increase the chances of success in breeding programs through germplasm characterization, evolutionary studies, and marker assisted selection (Creste et al., 2004, 2006).

The objective of the present study was to evaluate the discriminatory power of SSRs derived from the 'Calcutta 4' and 'Ouro' genomic libraries, and to analyze the genetic diversity of a representative sample of accessions from the Banana Germplasm Bank (BGB) at Embrapa Mandioca e Fruticultura.

\section{MATERIAL AND METHODS}

\section{Plant material}

Thirty accessions were selected from the BGB at Embrapa Mandioca e Fruticultura, located in Cruz das Almas in the State of Bahia, Brazil. Eight diploid (AA), 5 triploid (AAA), 4 triploid (AAB), 8 triploid (ABB), and 5 diploid (BB) accessions were selected (Table 1). It is worth mentioning that the BGB at Embrapa Mandioca e Fruticultura holds accessions that represent most of the available genetic variability in Musa spp worldwide.

\section{Acquisition of libraries}

Forty-four SSRs were used. The MaOCEN series of markers were developed by Creste et al. (2006) from the 'Ouro' diploid (AA) cultivar; 19 markers from the MaC series and 15 from the $\mathrm{MaO}$ series that were developed by Jesus et al. (2013) from the 'Calcutta 4' wild diploid (AA) and 'Ouro' cultivars, respectively, were also employed. The 'Ouro' and 'Calcutta 4' libraries were originally developed by Dr. Silvana Creste in the Plant Laboratory of Centro de Energia Nuclear na Agricultura at Universidade de São Paulo.

We also tested SSR markers from the mMaCIR series (mMaCIR151, mMaCIR156, mMaCIR196, mMaCIR241), described by Mbéguié-A-Mbéguié et al. (2007), and derived from a library enriched for the microsatellite motifs (CA)n and (TC)n from Musa acuminata 'Calcutta 4' and M. balbisiana 'Pisang Klutuk Wulung', and also used markers derived from the Musa acuminata 'Calcutta 4' EST-SSR library (mMECir 510, mMECir 519, mMECir 584) (Mbéguié-A-Mbéguié et al., 2007). Two other primers were also included in this study, namely, AGMI 121/122 (Lagoda et al., 1988) and Ma 1/17 (Crouch et al., 1998). In total, 44 markers were used to evaluate genetic diversity.

For the discriminatory power analysis, 38 markers were used ( 23 from the 'Calcutta 4' library and 15 from the 'Ouro' library,); for the genetic diversity studies, all 44 markers were used.

\section{DNA extraction}

Young banana leaves were collected from accessions at the BGB at Embrapa Mandioca e Fruticultura and used for genomic DNA extraction with the cetyltrimethylammonium bromide (CTAB) method (Doyle and Doyle, 1990). Briefly, approximately $300 \mathrm{mg}$ leaves 
was macerated in liquid nitrogen and transferred to $2.0-\mathrm{mL}$ microtubes. A preheated $\left(65^{\circ} \mathrm{C}\right)$ extraction buffer was then added $(1.4 \mathrm{M} \mathrm{NaCl} ; 100 \mathrm{mM}$ Tris- $\mathrm{HCl}, \mathrm{pH} 8.0 ; 20 \mathrm{mM}$ EDTA, $\mathrm{pH} 8.0 ; 1 \%$ polyvinylpyrrolidone MVV 10,$000 ; 2 \%$ CTAB; and $0.4 \% \beta$-mercaptoethanol), and the material in the tubes was homogenized for $5 \mathrm{~min}$. The samples were incubated in a water bath at $65^{\circ} \mathrm{C}$ for $45 \mathrm{~min}$ and homogenized every $15 \mathrm{~min}$. After this step, the samples were extracted twice with chloroform:isoamyl alcohol (24:1) and the supernatants collected by centrifugation at $10,000 \mathrm{rpm}$ for $10 \mathrm{~min}$. Ice-cold isopropyl alcohol was added to the supernatants. The material was incubated in a freezer for $30 \mathrm{~min}$ at $-20^{\circ} \mathrm{C}$ and centrifuged at $10,000 \mathrm{rpm}$ for $10 \mathrm{~min}$. The DNA pellet was washed with $70 \%$ ethanol and resuspended in TE (10 mM Tris- $\mathrm{HCl}, \mathrm{pH} 8.0,1 \mathrm{mM}$ EDTA) supplemented with ribonuclease $(10 \mathrm{mg} / \mathrm{mL}$ RNAse), dried in an oven at $37^{\circ} \mathrm{C}$, and then dissolved in $3.0 \mathrm{M}$ sodium acetate. The solution was centrifuged for $20 \mathrm{~s}$ at $3000 \mathrm{rpm}$. Ice-cold absolute ethanol was added to the supernatant, and the sample was centrifuged at $10,000 \mathrm{rpm}$. The DNA pellet was washed twice with $70 \%$ ethanol and resuspended in TE. Finally, the extracted DNA was stored at $-20^{\circ} \mathrm{C}$ in a freezer. Quantitative and qualitative evaluation of the extracted DNA was performed by comparative analysis of the samples on a $0.8 \%$ agarose gel using known molecular weight markers.

\section{DNA amplification}

PCR was carried out using a reaction mixture with a final volume of $15 \mu \mathrm{L}$ containing $2.5 \mathrm{mM} \mathrm{MgCl}{ }_{2}, 1 \mathrm{X}$ buffer, $0.2 \mathrm{mM}$ dNTPs, $0.2 \mu \mathrm{M}$ of each primer, 40 ng genomic DNA, and 1 $\mathrm{U} / \mu \mathrm{L}$ Taq DNA polymerase (Pluthero, 1993). Amplification was performed in an Applied Biosystems (ABI) Veriti 96-well thermal cycler using an annealing temperature specific for each primer. The amplification conditions included a 5 -min denaturation cycle at $94^{\circ} \mathrm{C}$, followed by 35 cycles of $1 \mathrm{~min}$ of denaturation at $94^{\circ} \mathrm{C}, 1 \mathrm{~min}$ of annealing at the specific annealing temperature of each primer and $1 \mathrm{~min}$ of extension at $72^{\circ} \mathrm{C}$. The final extension was $10 \mathrm{~min}$ at $72^{\circ} \mathrm{C}$, after which the reactions were held at $14^{\circ} \mathrm{C}$.

The amplification products were separated by electrophoresis on 3\% agarose gels at $100 \mathrm{~V}$ in $0.5 \mathrm{X}$ TBE buffer and stained with ethidium bromide $(0.5 \mu \mathrm{L} / \mathrm{mL})$. The amplified fragments were photo-documented using a Vilber Lourmat photo-documenter. The fragment sizes were determined based on a 50-bp DNA ladder (England Biolabs).

\section{Data analysis}

In order to evaluate the discriminatory power of the markers, two analyses were carried out. Due to the presence of triploid banana accessions among the sampled material, the first analysis considered the data in a binary ( 0 and 1$)$ manner; this analysis was performed with 30 accessions (both diploid and triploid). In the second analysis, the triploid individuals were removed, and fragment sizes (bp) were analyzed in 14 diploid accessions.

Genetic distance matrices were calculated using the GENES statistical program version 2009.7.0 (Cruz, 2006), based on Jaccard's (diploids and triploid accessions) and Nei and $\mathrm{Li}$ (1973) (diploid accessions) dissimilarity coefficients. Cluster analysis was performed using UPGMA (unweighted pair groups method with arithmetic mean), and a dendrogram was constructed using the Statistica software (Statistica for Windows, 2002). Groups were separated by a cut-off point following the criteria suggested by Mingoti (2005). Polymorphism information content (PIC) values were calculated using the formula: $\mathrm{PIC}=1-\Sigma \mathrm{pi}^{2}$ (Powell 
et al., 1996), where $p i$ is the frequency of allele $i$ in the population. The POWERMARKER software (Liu and Muse, 2005) was used for calculating PIC values. Discriminatory power was calculated through histograms.

\section{RESULTS}

\section{Discriminatory power of microsatellite loci derived from the 'Ouro' and 'Calcutta' genomic libraries}

\section{Considering the microsatellites as dominant markers}

Of the 134 markers initially tested, $44(33 \%)$ presented well defined polymorphic bands, $18(13 \%)$ were monomorphic, $40(30 \%)$ did not show any amplification product, and 32 (24\%) amplified samples with non-defined bands.

Thirty banana accessions were used for the evaluation of the discriminatory power of the primers derived from the 'Calcutta 4' and 'Ouro' libraries (Table 1). The samples were genotyped using 15 loci from the 'Ouro' library (MaO series) and 23 loci from the 'Calcutta 4' library (MaCCEN series, AGMI 121/122, Ma 1/17 and mMaCIR305). The marker data were treated as dominant, and 196 polymorphic bands were identified, with 80 and 116 bands from the 'Ouro' and 'Calcutta 4' primers, respectively. For the 'Ouro' library, the greatest number of alleles was obtained for MAOED01, with 8 alleles, while for 'Calcutta 4', MaC-CEN39 produced 10 alleles. The mean numbers of alleles per library analyzed were 5.06 and 5.13 for 'Ouro' and 'Calcutta 4', respectively (Table 2).

Table 1. Banana accessions from the BGB used in genetic diversity studies using SSR markers from 'Calcutta 4' and 'Ouro' libraries.

\begin{tabular}{|c|c|c|c|c|c|}
\hline No. & BGB & Accession & Genome & Subgroup/subspecies & Origin \\
\hline 1 & BGB7 & PA Mysore 3 & AA & Ssp. malaccensis derivada & Thailand \\
\hline 2 & BGB35 & NiyarmaYik & $\mathrm{AA}$ & Ssp. banksii & New Guinea \\
\hline 3 & BGB101 & Markatooa & AAA & - & New Guinea \\
\hline 4 & BGB105 & Pagatow & AAA & - & New Guinea \\
\hline 5 & BGB104 & Nam & AAA & - & Thailand \\
\hline 6 & BGB44 & TuuGia & AA & - & Hawaii \\
\hline 7 & BGB112 & Adimoo & AAB & - & New Guinea \\
\hline 8 & BGB127 & Yangambi Km 5 & AAA & Ibota & France \\
\hline 9 & BGB84 & Canela & AAA & - & Brazil \\
\hline 10 & BGB121 & Yangambi $\mathrm{N}^{\circ} 2$ & $\mathrm{AAB}$ & Silk(maça) & France \\
\hline 11 & BGB125 & Muísa Tia & ABB & Pisanawak & France \\
\hline 12 & BGB174 & Namwa Daeng & AAB & - & Thailand \\
\hline 13 & BGB147 & Cacambou Naine & ABB & Bluggoe & Ecuador \\
\hline 14 & BGB56 & IAC BB & BB & Balbisiana & Brazil \\
\hline 15 & BGB76 & Musa balbisiana & BB & Balbisiana & Brazil \\
\hline 16 & BGB169 & Samurá "B" & $\mathrm{AAB}$ & - & Brazil \\
\hline 17 & BGB175 & Ice cream & ABB & - & Hawaii \\
\hline 18 & BGB45 & KrasanSaichon & AA & - & Thailand \\
\hline 19 & BGB59 & Butuhan & BB & Balbisiana & Philippines \\
\hline 20 & BGB61 & Diploide Bélgica & BB & Balbisiana & Belgium \\
\hline 21 & BGB58 & BB França & BB & Balbisiana & France \\
\hline 22 & BGB73 & BB Panamá & BB & Balbisiana & Panama \\
\hline 23 & BGB10 & Calcutta 4 & AA & Ssp.burmannicoide & Jamaica \\
\hline 24 & BGB19 & Birmanie & AA & & France \\
\hline 25 & BGB37 & Malaccensis & AA & Ssp.malaccensis & Honduras \\
\hline 26 & BGB194 & Pelipita & $\mathrm{ABB}$ & Pelipita & Honduras \\
\hline 27 & BGB203 & Pacovan & AAB & Prata & Brazil \\
\hline 28 & BGB205 & Walha & $\mathrm{ABB}$ & Prata & Hawaii \\
\hline 29 & BGB214 & Saba Honduras & $\mathrm{ABB}$ & Saba & Honduras \\
\hline 30 & BGB68 & Ouro & AA & - & Brazil \\
\hline
\end{tabular}


Table 2. Microsatellite primers validated in banana accessions-forward (5'-3') and reverse (5'-3'), number of alleles, polymorphism information content (PIC), annealing temperature (Ta), size (bp) and faulty PCR.

\begin{tabular}{|c|c|c|c|c|c|c|c|}
\hline Library SSR locus & $F\left(5^{\prime}-3^{\prime}\right)$ & $\mathrm{R}\left(5^{\prime}-3^{\prime}\right)$ & No. of alleles & PIC & $\mathrm{Ta}^{\circ} \mathrm{C}$ & Size (bp) & No. Failed PCR \\
\hline \multicolumn{8}{|l|}{ Ouro } \\
\hline MaO-EC02 & Ggggaaggtggtgtagga & ggcaaatggaagagaggag & 5 & 0.233 & 58 & $200-300$ & 0 \\
\hline $\mathrm{MaO}-\mathrm{EC} 05$ & Tggagtcgetttttgctttt & gtggtgatttccgagtggtt & 5 & 0.228 & 58 & $100-200$ & 3 \\
\hline MaO-EC11 & Gcacaacettacteccatcac & cactacaactcaccettccaatc & 7 & 0.197 & 58 & $200-300$ & 0 \\
\hline MaO-FA12 & Cccgtgtattggtgtcgtag & gagactgatggcaaaggatg & 4 & 0.360 & 55 & $250-350$ & 1 \\
\hline $\mathrm{MaO}-\mathrm{FD} 02$ & Ggcatcacacacgcaaaa & attacattcccagcccacac & 5 & 0.209 & 56 & $150-250$ & 0 \\
\hline MaO-FF10 & Ctcetgttcttacetccgtgt & cgatgactggctttacttgtg & 5 & 0.144 & 56 & $200-300$ & 1 \\
\hline MaO-FG09 & Ttctttcctgaccaccttttc & ccaagtatcacaccaacacca & 5 & 0.231 & 58 & $100-200$ & 0 \\
\hline MaO-EH12 & Aacccaacaccaaaggaaga & atggaagcatgtggaggaac & 4 & 0.315 & 57 & $200-300$ & 0 \\
\hline $\mathrm{MaO}-\mathrm{EC} 09$ & Ggacttgtattttgtgcttcttc & atcatctccagccatctcc & 6 & 0.190 & 57 & $100-200$ & 1 \\
\hline MaO-ED01 & Tgttccacaggtttctcca & cgcatctatgacaacagcaa & 8 & 0.223 & 57 & $100-400$ & 4 \\
\hline MaOCEN03 & acc acgaggagcaggaaagtagc & ttcgggataggaggaggag & 5 & 0.277 & 55 & $200-350$ & 3 \\
\hline MaO-ED09 & Tgtcagataggtcggagttg & cgcatctatgacaacagcaa & 6 & 0.234 & 52 & $300-350$ & 2 \\
\hline $\mathrm{MaO}-\mathrm{EC} 12$ & Aacccaacaccaaaggaaga & tgtgggcggagaaataaatc & 4 & 0.290 & 52 & $100-250$ & 0 \\
\hline $\mathrm{MaO}-2 \mathrm{~B} 10$ & Acgaggagcaggaaagtagc & ttctcettatcccgtggttg & 5 & 0.335 & 52 & $200-250$ & 0 \\
\hline MaO-FH03 & ctatgggcgtgagtgcattgaatcccaagtttggtcaag & tctctttccetctettgecat & 4 & 0.227 & 52 & $200-300$ & 0 \\
\hline \multicolumn{8}{|l|}{ Calcutta 4} \\
\hline MaCEN3 & Ggaggaggaagaggagaagg & tgaactgacaccetgagcac & 6 & 0.210 & 57 & $100-200$ & 1 \\
\hline MaCEN4 & Tgtcagataggtcggagttg & agtgctcttgttaggtttcc & 6 & 0.274 & 57 & $100-300$ & 1 \\
\hline MaCEN5 & Atctcgetcacctcgtettc & tcatagacagcccagcagaa & 5 & 0.234 & 58 & $200-300$ & 0 \\
\hline MaCEN6 & Ttctgctgggetgtctatga & aagggcagttcacaacacaa & 5 & 0.247 & 57 & $250-300$ & 0 \\
\hline MaCEN10 & Atctgtgggettatggtcgt & gcaggtttgggagaagacat & 6 & 0.216 & 57 & $100-300$ & 1 \\
\hline MaC-CEN13 & Ttgttctccttgtgctcttga & tctctttccetctettgecat & 6 & 0.249 & 59 & $200-300$ & 5 \\
\hline MaCEN1 & Agatgatgacceccacetc & ttctcettatccegtggttg & 4 & 0.274 & 58 & $200-300$ & 0 \\
\hline MaC-CEN18 & Gcttcgtaccgetctcac & gegttcatccattttcatc & 4 & 0.272 & 56 & $200-250$ & 0 \\
\hline MaC-CEN19 & Ttcetgectttgcetgta & ggtttacccattgctctgac & 5 & 0.133 & 56 & $250-350$ & 2 \\
\hline MaC-CEN23 & Atagaaggaaacgggaaatc & aaaggagtttgtgtaggaagc & 5 & 0.214 & 56 & $200-400$ & 0 \\
\hline MaC-CEN34 & Gagaatggcaaatgtcaagt & ggtcccagtgtgttattgtc & 5 & 0.256 & 56 & $200-400$ & 4 \\
\hline MaC-CEN17 & Agaaacaaacagatacccga & ttccettatgtagtagcacca & 4 & 0.200 & 57 & $200-400$ & 0 \\
\hline MaC-CEN39 & Tggtgctgaattgaatctga & cgccacgaatacatctatct & 10 & 0.177 & 50 & $100-350$ & 4 \\
\hline MaC-CEN42 & Aatcttggttggettcetga & caaataaacctggggcattc & 5 & 0.193 & 54 & $200-300$ & 1 \\
\hline MaC-CEN44 & Gaaggcagggaacacgaa & tgagaagagcgagagaagca & 4 & 0.228 & 56 & $100-300$ & 4 \\
\hline MaC-CEN46 & Tgtaaggagectctgtgtgc & gagatgggattggtgttcgt & 4 & 0.227 & 52 & $200-300$ & 1 \\
\hline MaC-CEN52 & Tcactcggcagttcacaaag & gacttcatcttcggcaatgg & 5 & 0.301 & 52 & $200-300$ & 1 \\
\hline MaC-CEN56 & Cgaggagcaggaaagtagc & tgtgggcggagaaataaatc & 6 & 0.222 & 52.5 & $150-250$ & 0 \\
\hline Ma-CEN03 & ggctaggaaaggttagtggeggaggaggaagaggagaag & tgaactgacaccetgagcac & 6 & 0.257 & 56 & $100-300$ & 1 \\
\hline AGMI121/122 & accaacctaggaaacacagcagttggecgettgatctt & ggggtcaacatgttaagttct & 4 & 0.128 & 56 & $500-700$ & 2 \\
\hline AGMI73/74 & ggctaggaaaggttagtggccaacccagagctgectacg & agggtccaagaaactcctcc & 4 & 0.298 & 56 & $200-400$ & 2 \\
\hline mMaCIR305 & accaacctaggaaacacagtccgatcaattcagcca & tatgagcaagaacagccc & 3 & 0.289 & 56 & $300-350$ & 1 \\
\hline \multicolumn{8}{|c|}{ 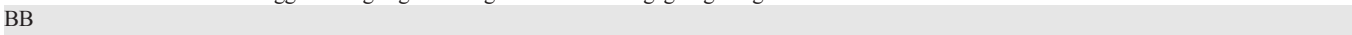 } \\
\hline mMECIR510 & gactatgggcgtgagtgcattggcgtttcctttgatg & atggttcggttggaagg & 4 & 0.330 & 56 & $100-200$ & 0 \\
\hline mMECIR519 & gactatgggcgtgagtgcatgatttcttgetgtggttttag & cgtgaaactcaggaggg & 6 & 0.223 & 56 & $100-250$ & 1 \\
\hline mMaCIR584 & gactatgggcgtgagtgcatggagataaggaagagagagagg & ctccaagcacagaagcac & 3 & 0.261 & 56 & $100-200$ & 0 \\
\hline \multicolumn{8}{|l|}{ Calcutta 4 EST } \\
\hline mMaCIR156 & ggctaggaaaggttagtggcctttctgaaggaaattctgac & agtgcagcccaatgaa & 4 & 0.300 & 56 & $200-250$ & 1 \\
\hline mMaCIR151 & gactatgggegtgagtgcattatccacctcctggcac & gecaaacatcacccaac & 6 & 0.238 & 56 & $100-200$ & 1 \\
\hline $\mathrm{mMaCIR} 241$ & accaacctaggaaacacagtgctaagcatcaagtagccc & acgaacaagcaatcaaagtag & 5 & 0.244 & 56 & $250-300$ & 2 \\
\hline \multicolumn{8}{|l|}{ Mean } \\
\hline General & - & - & 5.10 & 0.2529 & 55.7 & - & 1.2 \\
\hline Ouro & - & - & 5.06 & 0.2462 & 55.5 & - & 1.0 \\
\hline Calcutta 4 & - & - & 5.13 & 0.2334 & 55.6 & - & 1.4 \\
\hline $\mathrm{BB}$ & - & - & 4.00 & 0.271 & 56 & - & 0.3 \\
\hline Calcutta-4 EST & - & - & 4.50 & 0.261 & 56 & - & 1.25 \\
\hline
\end{tabular}

Primers used in the genetic diversity studies in banana accessions are marked in the shaded area.

The PIC values for the 44 polymorphic primers varied from 0.063 for the markers MaO-EC02, MaO-FD02, MaC-CEN56, and mMaCIR151 and 0.53 for the marker MaCCEN39. The mean PIC value across all markers was 0.24 . The mean value was relatively low 
because the evaluation included triploid accessions in which only the absence $(0)$ or presence (1) of bands can be assessed. This binary assessment leads to loss of information and therefore to low expected PIC values (Creste et al., 2003, 2004).

When the average PIC values between markers from the 'Calcutta 4' and 'Ouro' libraries were compared, there were no significant differences; the two libraries gave a discriminatory power of 0.233 and 0.246 , respectively (Table 2 ).

The highest degree of polymorphism was obtained with marker MaO-2H03 (10 alleles), while the lowest was obtained with markers Mmecir584-F, mMaCRI305-F, mMaCRI510-F, and mMaCRI241-F (3 alleles) (Table 2). The electrophoretic profiles of 30 banana accessions using marker MaCCen-28 are shown in Figure 1.

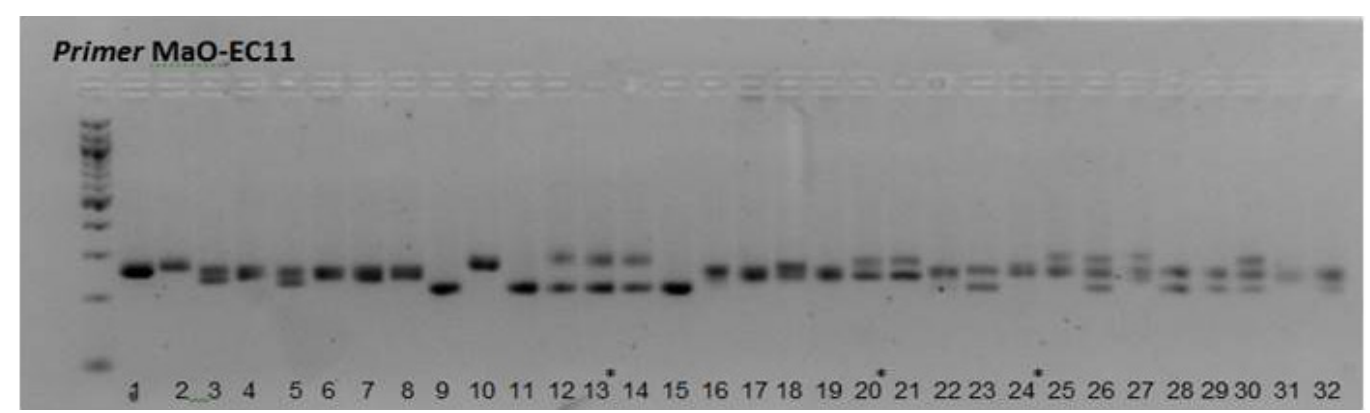

Figure 1. Eletrophoretic profile on agarose 1000,3\%. Lane $M=$ ladder $100 \mathrm{bp}$ (Invitrogen), primer MaO-EC11. Lanes 1-32: Pa Musore 3, Calcutta 4, Birmanie, NiyamaYik, Malaccensis, Tuu Gia, Krasan Saichon, NBF- 9, BB IAC, BB França, Butuhan, Diploide de Belgica, BB Panamá, *Balbisiana Franca, Musa balbisiana, Canela, Markatooa, Nam, Pagatow, Adimoo, *Tomnam, Yangambi No2, Muísa Tia, Yangambi Km 5, *ThapMaeo, CacambouNaine, Samurá "B", Namwa Daeng, Ice cream, Pelipita, Pacovan, Walha, and Saba Honduras. *Accessions that did not participate in all analysis for not being present at the BGB anymore during second DNA extraction. For this reason, were excluded from the total analysis.

The dissimilarity matrix based on Jaccard's index was used to compare the ability of the markers to discriminate among the accessions based on the two libraries analyzed (Figure 2). In general, the markers from the 'Ouro' library gave better discrimination of the accessions when treated as dominant data.

\section{Considering microsatellites as co-dominant markers}

Fourteen diploid banana plants were genotyped using 38 microsatellite markers and scored as co-dominants, allowing a more robust comparative analysis of the markers from the different libraries in terms of information content per locus. PIC values ranged from 0.380 to 0.795 for markers MaC-CEN39 and MaO-EC02, respectively, with a mean value of 0.614 (Table 3 ).

The electrophoretic profiles of 14 banana diploid accessions amplified with marker MaC-CEN52 are shown in Figure 3. PIC values over 0.50 were obtained for 90 and $87 \%$ of the primers from 'Calcutta 4' and 'Ouro' libraries, respectively (Figure 4). These PIC values are very high and should be taken into consideration in genetic variability studies of diploid bananas (Figure 5).

Using the co-dominant approach, the 'Calcutta 4' primers gave a better discrimination 
of the accessions than the markers from the 'Ouro' library.

\section{'Calcutta 4"}

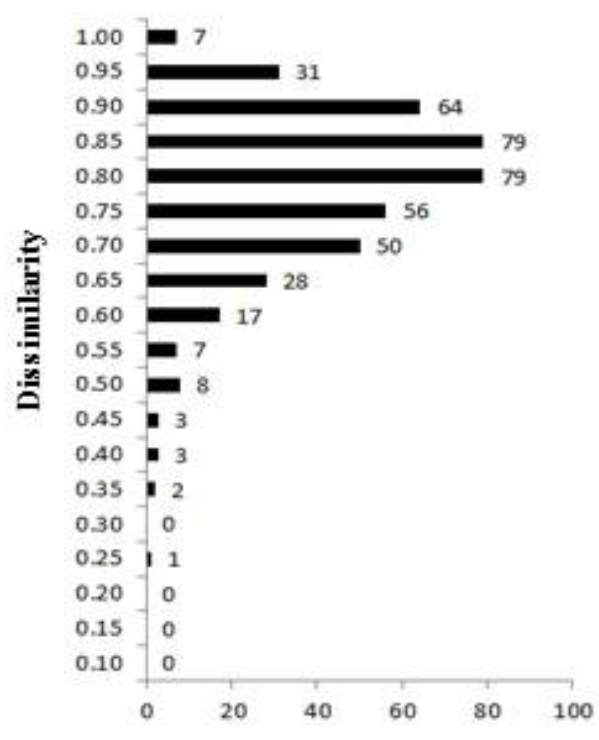

Number of dissimilarity pairs
'Ouro'

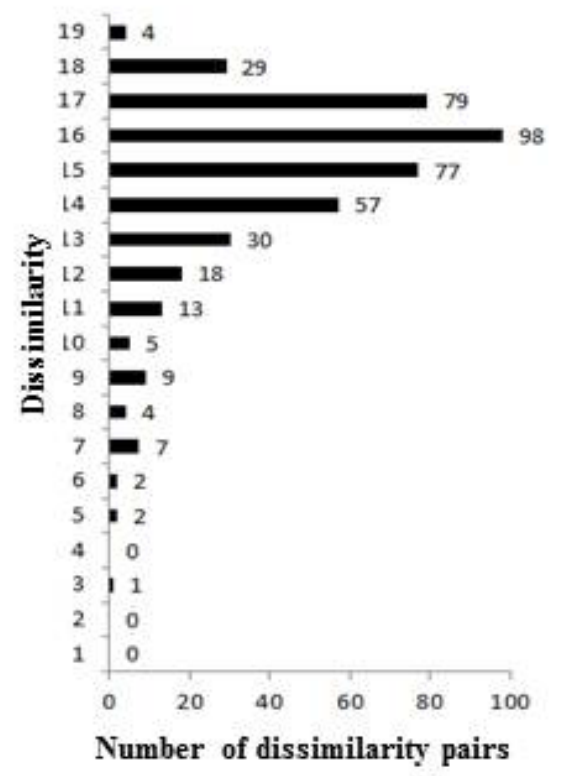

Figure 2. Dissimilarity between accession pairs, determined using microsatellite markers derived from the 'Ouro' and 'Calcutta 4' libraries, based on Jaccard's dissimilarity coefficient.

\section{Genetic diversity analysis of banana accessions}

\section{Considering the microsatellite markers as dominant markers}

We tested 134 SSRs: 101 originated from the 'Calcutta 4' wild diploid library (3 were 'Calcutta 4' EST-SSRs), 30 from the 'Ouro' library, and 3 from the 'Pisang Klutuk Wulung' library. In total, 44 were selected for analysis of the 30 banana accessions (diploid and triploids) (Table 1) because they exhibited satisfactory amplification results, generating from 3 to 10 alleles per locus (Table 2). Markers not analyzed here because they gave no amplification product or nonspecific products in the tests were excluded from this study but will be reexamined and validated in future studies after optimizing the PCR conditions. For the genetic diversity studies, we included markers from other sources to enhance the analysis. Thus, 3 EST-SSRs from the 'Calcutta 4' library EST-SSR library (mMECir 510, mMECir 519, and mMECir 584) and 3 markers from the 'Pisang Klutuk Wulung' (BB) library (mMaCIR151, mMaCIR156, and mMaCIR241) were used; these markers produced 28 bands. Overall, the 44 markers selected produced 224 polymorphic bands, with an average of 5.1 bands per marker. 
P.R.O. Silva et al.

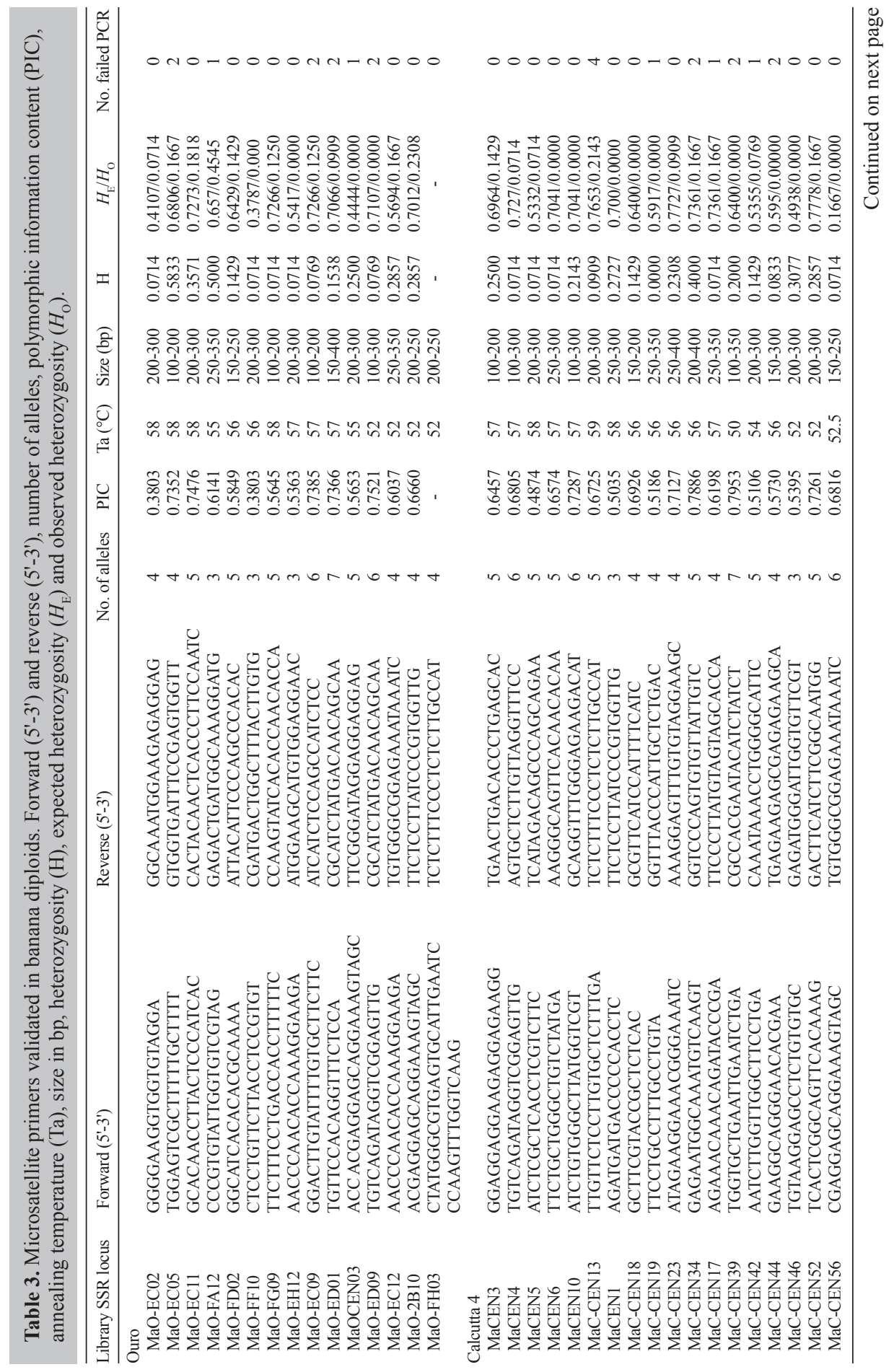


SSR markers from 'Calcutta 4' and 'Ouro' libraries

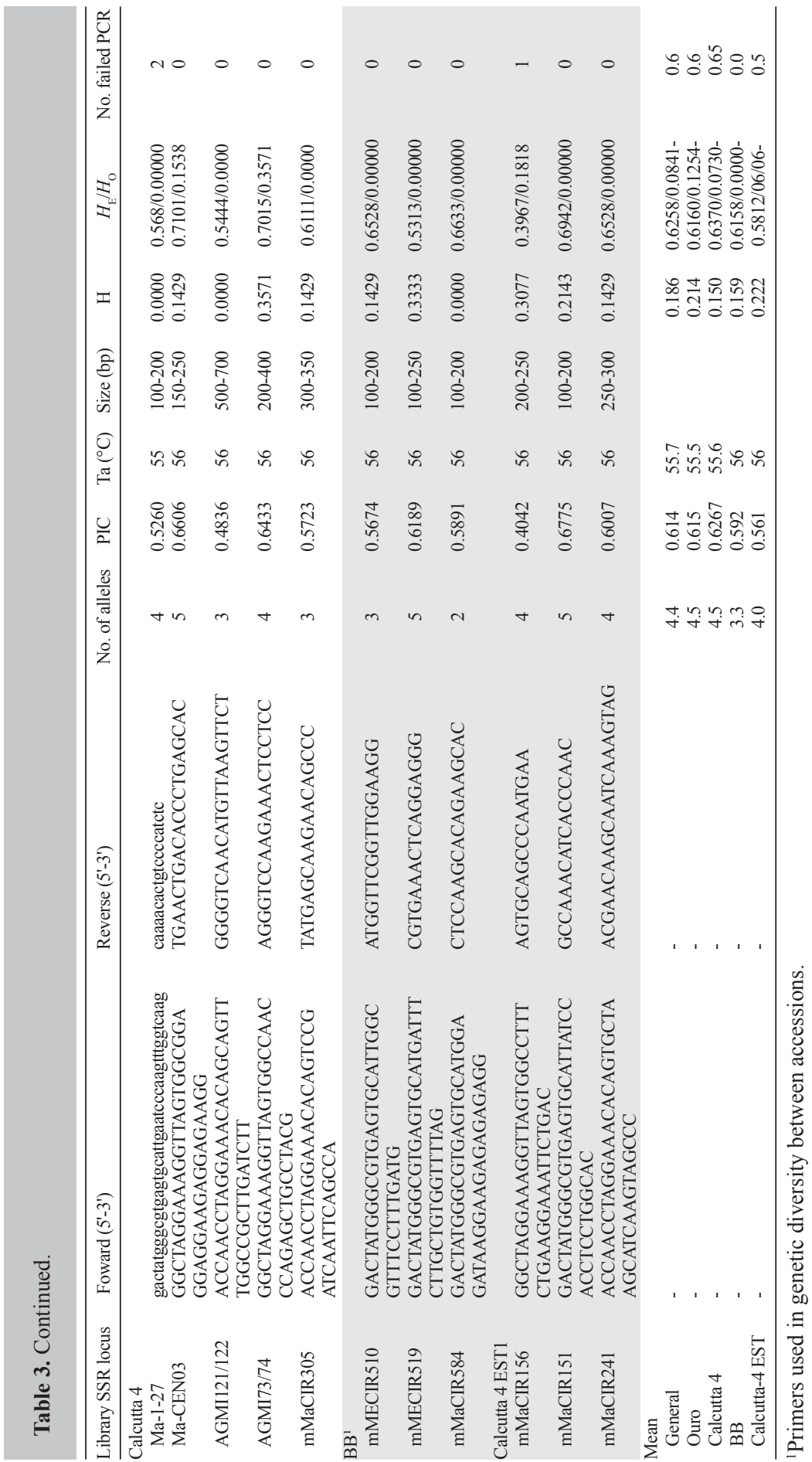




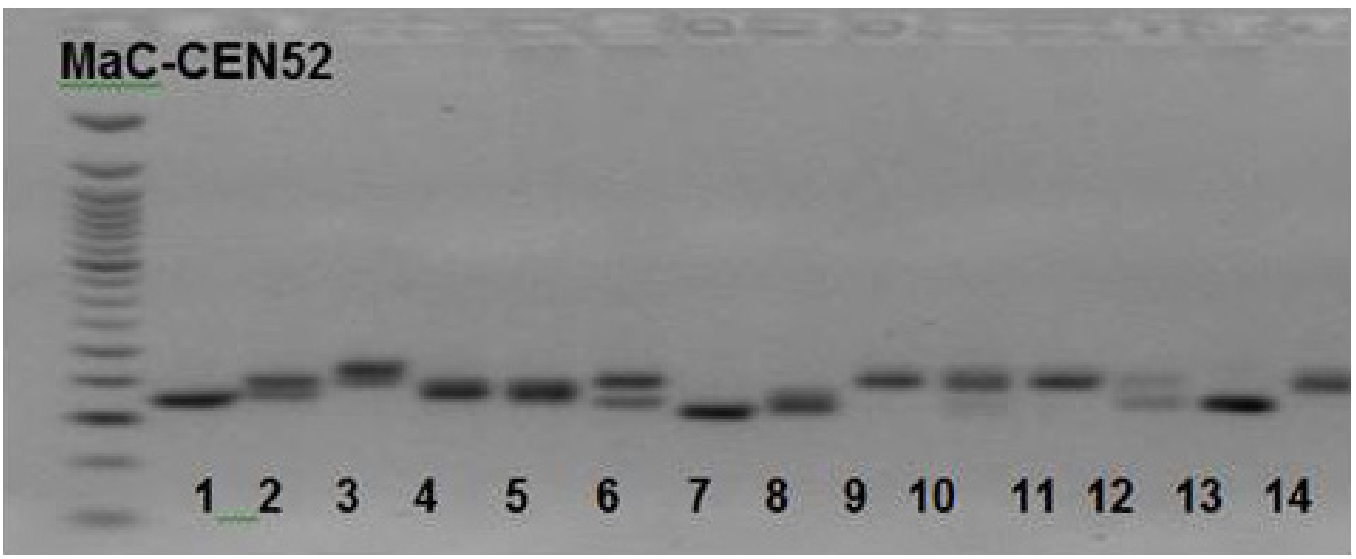

Figure 3. Eletrophoretic profile on agarose 1000, 3\% of 14 banana diploid accessions (lanes 1-14): Pa Mysore 3, Calcutta, Birmanle, NlyamaYlk, TuuGla, KrasanSalchon, BB Franca, Butuhan, Diploide de Belgica, BB Paraná, Balbisiana Franca, Musa balbisiana, BB IAC, Ouro. Lane $M=100$-bp ladder (Invitrogen), primer Mac CEN-52.
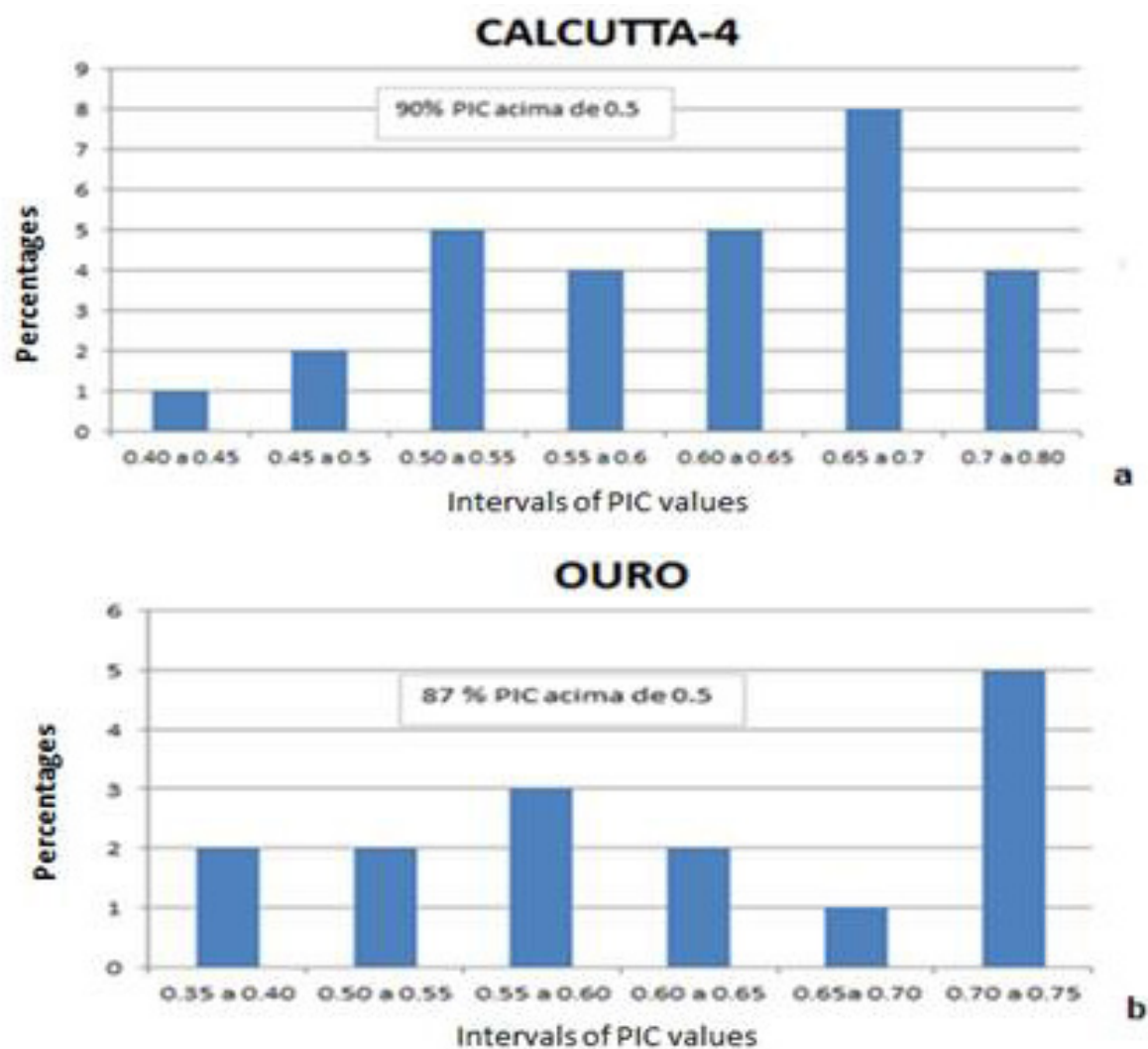

Figure 4. Distribution of PIC values above $0.50-90$ and $87 \%$ for primers from the "Calcutta-4" (a) and "Ouro" (b) libraries, respectively. 
a

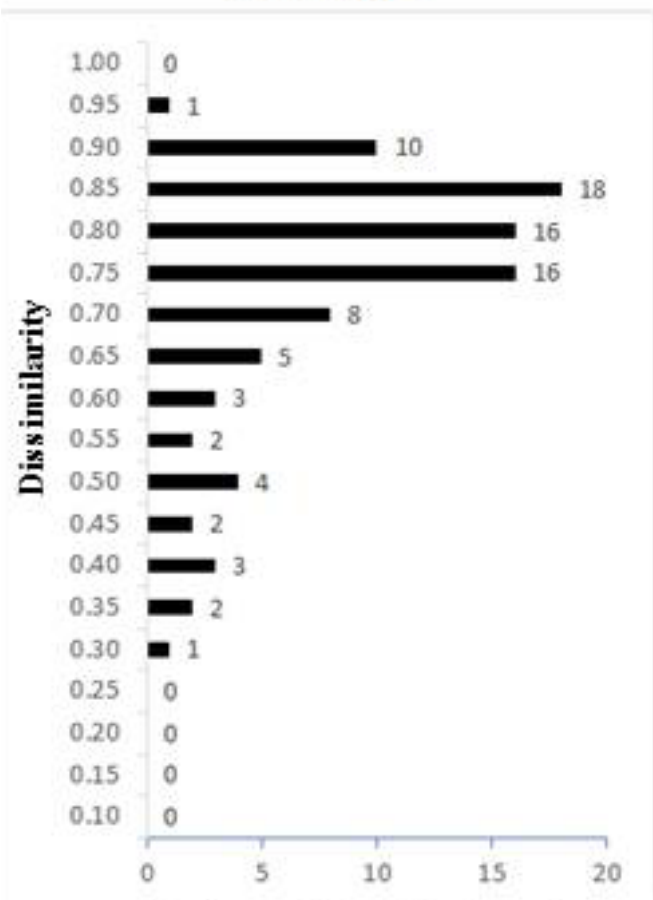

Number of dissimilarity pairs b

'Ouro'

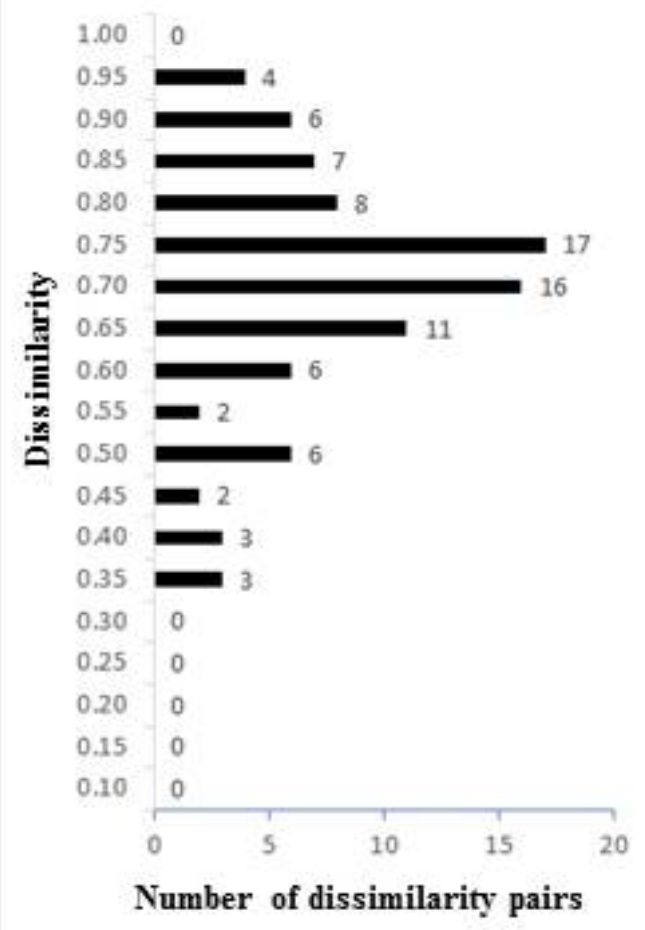

Figure 5. Distribution of PIC values above $0.50-90$ and $87 \%$ for primers from the 'Calcutta4' (a) and 'Ouro' (b) libraries, respectively.

To study genetic variability in the 30 banana accessions, we constructed a dendrogram using the data from the 44 primers and 224 polymorphic bands as dominant markers (Figure 6). This dendrogram indicated the presence of genetic variability among the accessions present in the BGB-Banana at Embrapa.

The evaluation of genetic similarity using microsatellite markers in polyploid accessions has a low level of association with real similarity since it is not possible to capture the maximum discrimination power as is possible with bp distances.

\section{Considering microsatellite markers as co-dominant markers}

For the genetic diversity analysis, we used the genotyping data from the 44 markers in 14 banana diploid accessions and considered the data as co-dominant markers (Figure 7).

Two distinct groups were formed, namely G1 and G2. The G1 group was composed of only B genome individuals, while the G2 group was composed of A genome individuals. This result is in accord with that reported by Jesus et al. (2013), who suggested that it was possible to observe a perfect separation between accessions with A (M. acuminata) or B (M. balbisiana) genomes. This conclusion is expected from the different species because of the robustness of co-dominant SSR markers. 


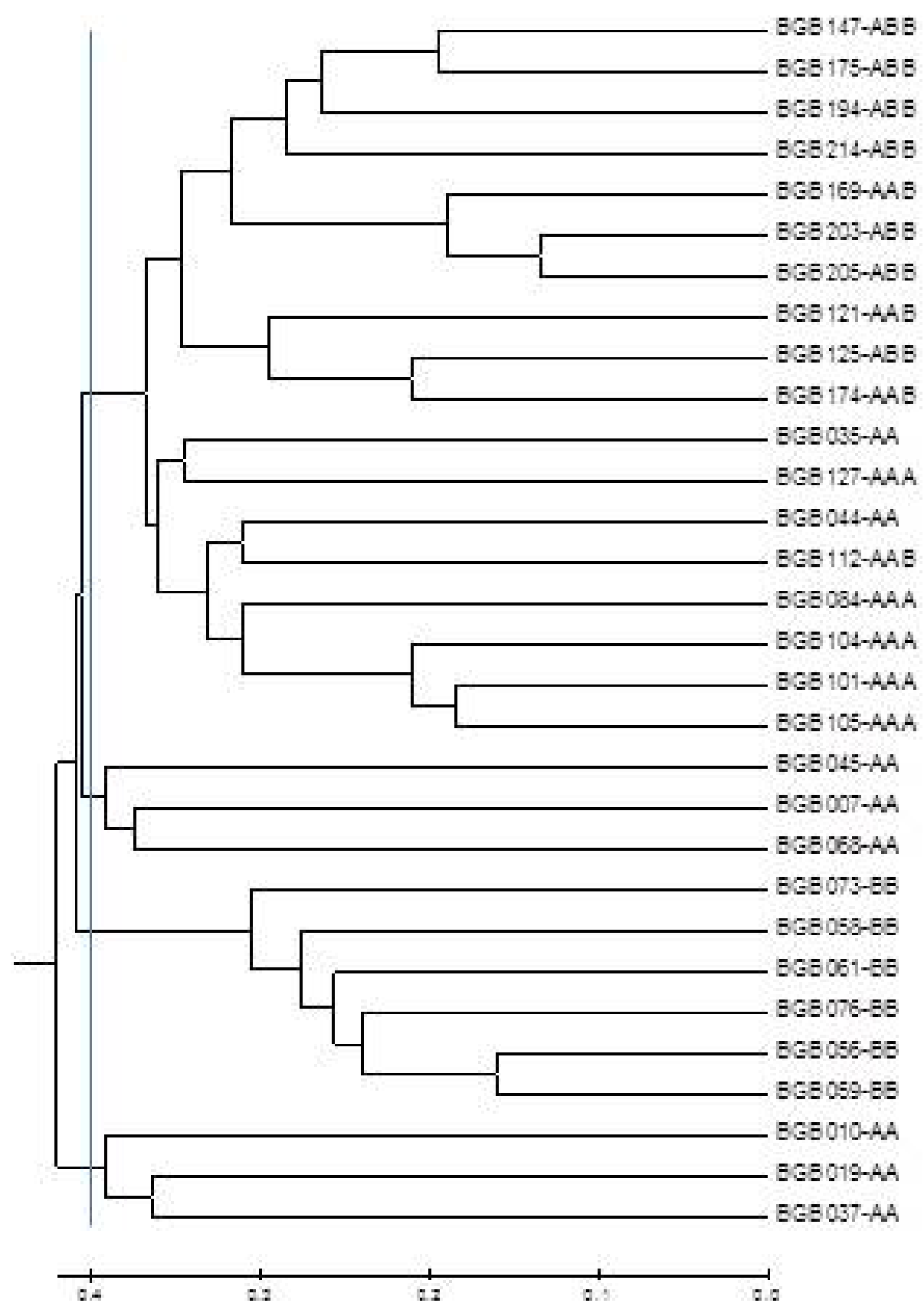

Figure 6. Genetic distance among 30 banana genotypes using 44 primers and 224 polymorphic bands. The genotypes were 1-30 (see Table 4). The distance matrix was generated using Jaccard's genetic dissimilarity index using the GENES software (Cruz et al., 2003). Groups were formed using the UPGMA method with the STATISTICA software (Statistica for windows, 2002). 
Genetic variability is of fundamental importance for breeding of any species (Lakshmanan et al., 2007). Knowledge of genetic distances in Musa spp accessions also deserves attention along with phenotypic data to aid breeding in the species.

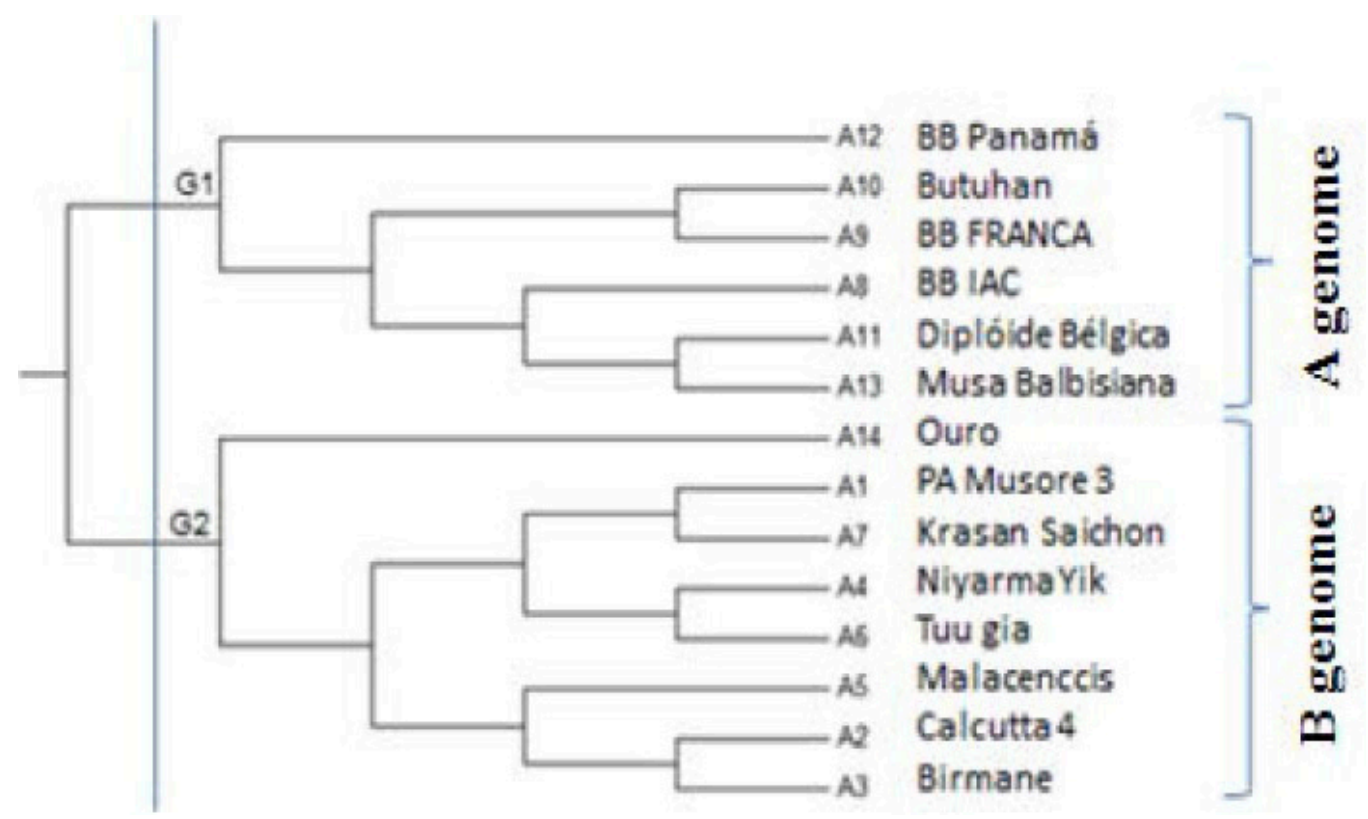

Figure 7. Genetic distances among 14 banana diploids, as obtained from 44 microsatellite markers and 224 polymorphic bands. The genetic distance matrix was created using the shared alleles index, and the groups were created using the UPGMA command in the POWERMARKER software (Liu and Muse, 2005).

\section{DISCUSSION}

\section{Discriminatory power of microsatellite loci derived from the 'Ouro' and 'Calcutta 4' genomic libraries}

\section{Considering microsatellites as dominant markers}

Two genomic constitutions, A and B, are recognized in bananas. Different cultivars can have different levels of ploidy for the basic chromosome number of 11: diploid (2n), triploid (3n), and tetraploid (4n). These cultivars also show variation in their genomic constitutions: $\mathrm{AA}, \mathrm{AB}$, and $\mathrm{BB}$ in diploids; $\mathrm{AAA}, \mathrm{AAB}$, and $\mathrm{ABB}$ in triploids; and $\mathrm{AAAA}, \mathrm{AAAB}$, AABB, and ABBB in tetraploids (Simmonds and Shepherd, 1955).

This genomic constitution hinders statistical analyses of many parameters associated with genetic variation; thus, when triploid or tetraploid genotypes are involved, the markers are scored as dominant, causing a loss of informative power (Creste et al., 2003, 2004). These difficulties are reflected in the breeding of banana cultivars because of incompatibility and sterility, which hinder production of segregating populations, and the presence of duplications, inversions, and translocations, which make genotyping more difficult.

In our study, only 44 of the 134 markers tested showed reproducible PCR products. 
Since triploid genotypes were used, it was not possible to analyze the data as co-dominant. In this first analysis, the mean number of alleles from both 'Ouro' and 'Calcutta 4' libraries (5.06 and 5.13, respectively) did not vary significantly (Table 2 ). The PIC values obtained were as expected being below 0.5 with a very low average $(0.24)$ due to the use of the data as dominant markers. The average values did not vary between the markers in both libraries. These low values demonstrate how information is lost when this approach is used.

Our results are consistent with those of Creste et al. $(2003,2004)$ in studies using SSR markers in Musa spp; the fragments were also computed as binary data due to the polyploid character and chromosome duplications in the species (Crouch et al., 1998). PIC values decreased accordingly.

In general, the markers from the 'Ouro' library provided better discrimination of the accessions with $65.98 \%$ ( 287 of the 435 pairs of accessions) showing dissimilarity above $80 \%$. Although a higher number of markers were analyzed from the 'Calcutta 4' library, the analysis yielded $59.77 \%$ of dissimilarity pairs above $80 \%$.

Although only a small number of primers were analyzed here, our analysis indicated that if it is necessary to use the dominant approach, then the markers from the 'Ouro' library are more suitable. This conclusion is supported by the fact that the 30 accessions used here were selected as being representative of the variability in banana germplasm collections.

\section{Considering microsatellites as co-dominant markers}

Fourteen diploid banana individuals were genotyped using 44 microsatellite markers and scored as co-dominant data. As expected, average PIC values for both libraries were high (0.614) in this analysis compared to the dominant analysis $(0.24)$. The highest PIC value for the 'Calcutta 4' library was 0.7886 (marker MaC-CEN34) and for the 'Ouro' library was 0.7521 (marker MaO-ED09). The results of this analysis show that PIC values increase in diploid individuals; a similar outcome was reported by Creste et al. (2003). The fact that almost $90 \%$ of the PIC values from both libraries were over 0.5 demonstrates a high discriminatory capacity among banana accessions, and that these markers are suitable for genetic diversity studies, investigating population structure, and for mapping.

In this co-dominant analysis, the markers from the 'Calcutta 4' library gave better discrimination of the accessions with $49.45 \%$ of pairs of accessions showing dissimilarity above $80 \%$ in comparison to $27.47 \%$ from the 'Ouro' library.

The size of the products amplified by the SSR primer pairs mainly ranged from 150 to $500 \mathrm{bp}$. Only the AGMI121/122 primer pair amplified a larger product (700 bp) (Table 3). The range of fragment sizes indicates the feasibility of using multiplex methodologies, e.g., multiplex PCR, which allow the analysis of a large number of samples in a short time period with lower overall cost.

\section{Genetic diversity analysis of banana accessions}

\section{Considering the microsatellite markers as dominant}

According to the suggested cut-off (Mingoti, 2005) the accessions could be separated into main four groups: G1) three AA diploids (Calcutta AA, Birmanie AA, Malaccensis AA); G2) three AA diploids (Ouro AA, PA Musore 3 AA, Krasan Saichon AA); G3) two diploids 
and 16 triploids [Cacambou Naine ABB, Ice cream (Havai) ABB, Pelipita ABB, Saba Honduras ABB, Samurá "B" AAB, Pacovan AAB, Walha AAB, Yangambi N 2 AAB, Muísa Tia ABB, Namwa Daeng ABB, Niyarma Yik AA, Yangambi Km 5 AAA, Tuu Gia AA, Adimoo AAB, Canela AAA, Nam AAA, Markatooa AAA, and Pagatow AAA]; and G4) six BB diploids (Butuhan BB, IAC BB, Musa balbisiana BB, Diploide de Belgica BB, França BB and Panamá BB).

Although cluster analysis achieved some separation of groups on genomic constitution, it was generally not possible to group them exclusively on the basis of genomic constitution, subgroup, subspecies, or origin; for example, some diploid accessions were grouped with triploids of the ABB or AAA types.

In group 1, the three cultivars were all diploid (AA) and two, the Birmanie and Calcutta accessions, belonged to the subspecies complex Birmannica/burmannicoides/simea that originated in Northeast India, Burma, southeast China, and Thailand. This, according to Jesus et al. (2013), justifies their grouping since they are genetically close to the malaccensis subspecies of the Malaysian peninsula. The three accessions in group 2 were all diploid, while two, Mysore 3 and Krasan Saichon, shared the same origin in Thailand.

All of the AAA, AAB, and $\mathrm{ABB}$ triploids and two AA diploids were present in group 3. The Pacovan (BGB 203) and Walha (BGB 205) accessions, which belong to the Prata subgroup and are characterized by sweet fruits, sweet aroma, low acidity and light digestion, also belong to group 3 (Moreira, 1999). Similar results were reported by Jesus et al. (2013) who studied accessions from the Prata subgroup using microsatellite markers.

The Cacambou Naine and Ice Cream accessions, which both have an ABB genotype, were also in group 3. A similar grouping was suggested by Brandão et al. (2011) in an analysis of genetic variability in banana genotypes using phenotypic characteristics. The Niyarmar Yik, Markatooa (BGB 101), Pagatow (BGB 105) and Adimoo (BGB 112) accessions were assigned to group 3 and have the same origin in New Guinea. Accessions with BB genomes were assigned to group 4; similar results were reported by Jesus et al. (2013).

Analysis of the dendrogram indicated the presence of genetic variability among the accessions held at BGB-Banana at Embrapa. This variability can be attributed to the different origins of the accessions and to the differences in ploidy levels. In accord with our results, Mattos et al. (2010) reported the impossibility of obtaining a perfect separation of genotypes due to the presence or absence of genome B. It is also worth mentioning that separation by genomic constitution may be more effective when greater representation of the genetic variability is present, as this would favor a more precise comparison of inter- and intra-genomic constitutions and ploidy levels. In all the groups formed in our analysis, there was sufficient variability for exploitation in breeding programs. The 'Ouro' and 'Muísa Tia' genotypes were separated by the largest genetic distance (0.93) of the accessions tested. The most closely related accessions were 'Pacovan' and 'Walha' with a genetic distance value of 0.35 . The mean genetic distance value obtained for all studied accessions was $0.74 \%$. Our results are similar to those of Mattos (2009), who found a mean genetic distance of 0.34 between banana accessions; in their study, genetic distance varied from 0.001 between triploid 'Pacha Nadan' and diploid 'Jaran', to 0.76 between the accessions M- 48 and 'Caru'.

\section{Considering microsatellite markers as co-dominant}

Two distinct groups (G1 and G2) were formed using the data as co-dominant mark- 
ers. G1 was composed of only B genome individuals, while G2 was composed of A genome individuals. This result is in agreement with the report of Jesus (2013) who suggested it was possible to observe a perfect separation between accessions with $\mathrm{A}(M$. acuminata) and $\mathrm{B}(M$. balbisiana) genomes. This separation is likely due to the fact that the genomes originate from different species and from the robustness of co-dominant SSR markers.

The dissimilarity matrix, based on the Nei and Li (1973) index, was used to determine the genetic distances between the diploids analyzed. The accessions 'Diploide Belgica' and 'Calcutta 4', 'Birmani' and 'Pa Musore 3' were the most dissimilar (0.85\%) and 'Ouro' and 'Calcutta 4 ' were the most similar $(0.32 \%)$. The average genetic distance between accessions was $0.68 \%$. Similar results were reported by Creste (2004) where the 'Pa Musore 3' and 'Birmanie' accessions were most dissimilar.

Creste et al. (2004) used SSR markers to study genetic diversity in 49 diploid accessions from the same germplasm bank as here and reported an average genetic similarity of $10 \%$. Librelon et al. (2013) examined genetic diversity of 'Prata-Anã' clones and observed that the 'Prata-Anã Gorutuba' clones and the cultivar 'Prata-Anã' showed similarity of $89 \%$, with an average distance of $40.77 \%$ between the clones evaluated.

Genetic variability is of fundamental importance for breeding of any species (Lakshmanan et al., 2007). Amorim et al. (2008) suggested that parental combinations could be identified using genetic distances between diploids and that this might be the key to choosing genotypes for crosses to develop improved diploids to increase the genetic base of the species.

In the comparison of genetic distances in the dominant and co-dominant dissimilarity matrices, most accessions maintained parsimony, e.g., 'Pa Musore'/'Calcutta 4' (77\%), 'Pa Musore'/'Birmani' (82\%) and 'Tu Guia'/'IAC BB' (87\%). Here, genetic distances between accessions were found to be relatively constant when comparing results between the analysis of co-dominant markers and separate analyses of 'Ouro' and 'Calcutta 4' libraries.

\section{CONCLUSIONS}

The SSR markers validated in this study proved to be efficient for the analysis of genetic diversity in Musa spp. We found genetic variability among the evaluated accessions, which provides important information for breeding programs and for the possible development of new cultivars using diploid and triploid accessions. The markers were not able to separate the accessions by their origin, but only by their genomic constitution. Markers from both the 'Calcutta 4' and 'Ouro' libraries were equally appropriate for the analysis of genetic diversity in Musa spp.

\section{Conflicts of interest}

The authors declare no conflict of interest.

\section{ACKNOWLEDGMENTS}

The authors would like to thank FAPESB (Fundação de Amparo à Pesquisa do Estado da Bahia) for the scholarship to the first author and Embrapa Mandioca e Fruticultura 
for financial support.

\section{REFERENCES}

Amorim EP, Reis RV, Amorim VBO, Santos-Serejo JA, et al. (2008). Variabilidade genética estimada entre diploides de banana por meio de marcadores microssatélites. Pesq. Agropec. Bras. 43: 1045-1052.

Amorim EP, Lessa LS, Ledo CAS, Amorim VBO, et al. (2009). Caracterização agronômica e molecular de genótipos diploides melhorados de bananeira. Rev. Bras. Frutic. 31: 154-161.

Amorim EP, Santos-Serejo J, Amorim V, Ferreira CF, et al. (2013). Banana breeding at Embrapa Cassava and Fruits. Acta Hort. (ISHS) 986: 171-176.

Anuário Brasileiro da Fruticultura (2014). Anuário Brasileiro da Fruticultura. Gazeta Santa Cruz, Santa Cruz do Sul, 136.

Borrone JW, Brown JÁ, Tondo CL, Mauro-Herrea M, et al. (2009). An EST-SSR-based linkage map for Persea americana Mill. (avocado). Tree Genet. Genomes 5: 553-560.

Brandão LP, Amorim AP, Souza CPF, Santos-Serejo JÁ, et al. (2011). Variabilidade genética em acessos de bananeira por meio de procedimentos uni e multivariados. Congresso Brasileiro de Melhoramento genético de plantas no Brasil: [anais]. Búzios, 1 CD-ROM, 4.

Buso GSC, Ciampi AY, Moretzsohn MC and Amaral ZPS (2003). Protocolo para desenvolvimento de marcadores microssatélites. Circ. Tecn. 20, EMBRAPA 11.

Creste S, Tulmann Neto A, Silva SO and Figueira A (2003). Genetic characterization of banana cultivars (Musa spp.) from Brazil using microsatellite markers. Euphytica 132: 259-268.

Creste S, Neto AT, Vencovsky R, Silva SO, et al. (2004). Genetic diversity of Musa diploid and triploid accessions from the Brazilian banana breeding program estimated by microsatellite markers. Genet. Resour. Crop Evol. 51: 723-733.

Creste S, Benatti T, Orsi MR, Risterucci AM, et al. (2006). Isolation and characterization of microsatellite loci from a commercial cultivar of Musa acuminata. Mol. Ecol. Notes 6: 303-306.

Crouch HK, Crouch JH, Jarret RL, Cregan PB, et al. (1998). Segregation at microsatellite loci in haploid and diploid gametes of Musa. Crop Sci. 38: 211-217.

Cruz CD (2003). Programa Genes: Biometria. Editora UFV, Viçosa.

Cruz CD (2006). Programa GENES. Aplicativo computacional em genética e estatística. UFV, Viçosa, 1: 442.

D'Hont A, Denoeud F, Aury J-M, Baurens F-C, et al. (2012). The banana (Musa acuminata) genome and the evolution of monocotyledonous plants. Nature 488: 213-217.

Doyle JJ and Doyle JL (1990). Isolation of plant DNA from fresh tissue. Focus 12: 13-15.

FAO (2014). Food and Agriculture Organization Database of the United Nations. Available at [http://faostat.fao.org]. Accessed June 12.

Fauré S, Noyer JL, Horry JP, Bakry F, et al. (1993). A molecular marker-based linkage map of diploid bananas (Musa acuminata). Theor. Appl. Genet. 87: 517-526.

Ferreira ME and Grattapaglia D (1998). Introdução ao uso de marcadores moleculares em análise genética. 2nd edn. EMBRAPA - CENARGEN, Brasília.

Hippolyte I, Bakry F, Seguin M, Gardes L, et al. (2010). A saturated SSR/DArT linkage map of Musa acuminata addressing genome rearrangements among bananas. BMC Plant Biol. 10: 65.

Jesus ON, Camara TR, Ferreira CF, Silva SO, et al. (2006). Diferenciação molecular de cultivares elites de bananeira. Pesq. Agropec. Bras. 41: 1739-1748.

Jesus ON, Ferreira CF, Silva SO, Camara TR, et al. (2009). Characterization of recommended banana cultivars using morphological and molecular descriptors. Crop Breeding Appl. Biotech. 9: 164-173.

Jesus ON, Silva SO, Amorim EP, Ferreira CF, et al. (2013). Genetic diversity and population structure of Musa accessions in ex situ conservation. BMC Plant Biol. 13: 41.

Lagoda PJL, Noyer JL, Dambier D, Baurens FC, et al. (1998). Seqüência local microssatélites marcados (STM) marcadores no Musaceae. Mol. Ecol. 7: 657-666.

Librelon SS, Costa MR, Nietsche S and Pereira MCT (2013). Diversidade genética de clones de bananeira 'Prata-Anã' (AAB) por meio de marcadores SSR. Rev. Bras. Frutic. 35: 809-817.

Lakshmanan V, Sreedhar RV and Bhagyalakshimi N (2007). Molecular analysis of genetic stability in long-term micropropagated shoots of banana using RAPD and ISSR markers. Electron. J. Biotechnol. 10: 106-113.

Liu K and Muse SV (2005). PowerMarker: an integrated analysis environment for genetic marker analysis. Bioinformatics 21: 2128-2129.

Mattos LA (2009). Caracterização de Acessos de Bananeira. Master's thesis. Universidade Estadual de Feira de Santana, Feira de Santana. 
Mattos LA, Amorim EP, Amorim VBO, Cohen, K, et al. (2010). Agronomical and molecular characterization of banana germplasm. Pesq. Agropec. Bras. 45: 146-154.

Mbanjo EGN, Tchoumbougnang F, Nyine M, Dochez C, et al. (2009). An EST-based SSR genomic resource for bananas. International Plant Animal Genomes XVII Conference, San Diego.

Mbéguié-A-Mbéguié D, Hubert O, Sabau X, Chillet M, et al. (2007). Use of suppression subtractive hybridization approach to identify genes differentially expressed during early banana fruit development undergoing changes in ethylene responsiveness. Plant Sci. 172:1025-1036.

Mingoti SA (2005). Análise de dados através de métodos de estatística multivarida: uma abordagem aplicada. Editora UFMG, Belo Horizonte.

Moreira RS (1999). Banana-Teoria e Prática de Cultivo. 2nd edn. Fundação Cargill, São Paulo.

Nei M and Li W-H (1973). Linkage disequilibrium in subdivided populations. Genetics 75: 213-219.

Pluthero FG (1993). Rapid purification of high-activity Taq DNA polymerase. Nucleic Acids Res. 21: 4850-4851.

Powell WW, Koput KW and Smith-Doerr L (1996). Interorganizational collaboration and the locus of innovation: networks of learning in biotechnology. Admin. Sci. Quarterly 41: 116-45.

Salla MFS, Ruas CF, Ruas PM and Carpentieri-Pipolo V (2002). Uso de marcadores moleculares na análise da variabilidade genética em acerola (Malpighia emarginata D.C.). Rev. Bras. Frutic. 24: 15-22.

Sharon D, Cregan PB, Mhameed S, Kusharshka K, et al. (1997). An integrated genetic linkage map of avocado. Theoret. Appl. Genet. 95: 911-921.

Silva SDA, Antunes LEC, Anthonisen DG, Genões JS, et al. (2008). Caracterização de genótipos de mirtilo utilizando marcadores moleculares. Rev. Bras. Frutic. 30: 180-184.

Silva SO, Amorim EP, Santos-Serejo JA, Ferreira CF, et al. (2013). Melhoramento genético da bananeira: estratégias e tecnologias disponíveis. Rev. Bras. Frutic. 35: 919-931.

Simmonds NW and Shepherd K (1955). The taxonomy and origin of the cultivated bananas. Bot. J. Linnean Soc. 55: 302-312.

Statistica for Windows (2002). Computer program manual. Version 6. Tulsa: Statsoft, 1CD-ROM. 